\title{
Analisis Perbedaan Kinerja Perusahaan antara Perusahaan yang Terindeks LQ45 dengan Perusahaan Non LQ45
}

\author{
Ida Ayu Nyoman Utari Gandawati ${ }^{1}$ \\ Fakultas Ekonomi dan Bisnis \\ Universitas Udayana, Indonesia
}

\author{
Made Gede Wirakusuma ${ }^{2}$ \\ Fakultas Ekonomi dan Bisnis \\ Universitas Udayana, Indonesia
}

\begin{abstract}
Surel : dayuutarii@gmail.com
ABSTRAK

Penelitian ini bertujuan untuk mengetahui dan mendapatkan bukti empiris mengenai perbandingan kinerja perusahaan pada perusahaan terindeks LQ45 dan perusahaan non LQ45. Penelitian ini dilakukan pada perusahaan LQ45 dan non LQ45 non keuangan yang terdaftar di Bursa Efek Indonesia tahun 2016-2018. Sampel penelitian ini dipilih dengan menggunakan teknik purposive sampling dan diperoleh sebanyak 45 perusahaan non keuangan untuk masing-masing kelompok perusahaan terindeks LQ45 dan non LQ45, sehingga jumlah amatan dalam penelitian ini adalah sebanyak 270 amatan. Teknik analisis data yang digunakan adalah Mann-Whitney U Test. Hasil penelitian menunjukkan bahwa kelompok perusahaan yang terindeks LQ45 memiliki rata-rata likuiditas dan profitabilitas yang lebih tinggi dibandingkan perusahaan non LQ45, sedangkan dari segi ratarata nilai leverage perusahaan LQ45 bernilai lebih rendah dibadingkan dengan perusahaan non LQ45.
\end{abstract}

Kata Kunci: Kinerja Perusahaan; LQ45; Non LQ45.

\section{Analysis The Difference of Company Performance Between LQ45 Indexed Companies with Non LQ45 Companies}

\begin{abstract}
This study aims to determine and obtain empirical evidence about the difference performance of companies in LQ45 indexed companies and non-LQ45 companies. This research was conducted at non-financial companies on LQ45 indexed companies and non-LQ45 companies listed on the Indonesia Stock Exchange in 2016-2018. The sample of this study is chosen using purposive sampling technique and 45 nonfinancial companies were obtained for each LQ45 and non-LQ45 indexed group of companies, so the number of observations in this study was 270 observations. The data analysis technique used is the MannWhitney U Test. The results showed that the LQ45 indexed group of companies had a higher average liquidity and profitability compared to non-LQ45 companies, while in terms of average the leverage value of $L Q 45$ companies was lower compared to non-LQ45 companies.
\end{abstract}

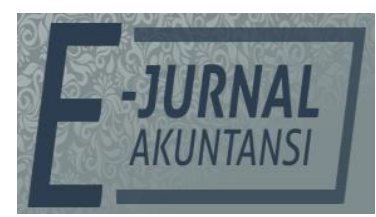

e-ISSN 2302-8556

Vol. 30 No. 10

Denpasar, Oktober 2020

Hal. 2500-2513

DOI:

10.24843/EJA.2020.v30.i10.p05

PENGUTIPAN:

Gandawati, I. A. N. U. \&

Wirakusuma, M. G. (2020).

Analisis Perbedaan Kinerja Perusahaan antara

Perusahaan yang Terindeks LQ45 dengan Perusahaan Non LQ45. E-Jurnal Akuntansi, 30(10), 2500-2513

RIWAYAT ARTIKEL:

Artikel Masuk: 13 Februari 2020 Artikel Diterima: 6 Juli 2020

Keywords: $\quad$ Company Performance; LQ45; Non LQ45.

Artikel dapat diakses : https://ojs.unud.ac.id/index.php/Akuntansi/index 


\section{PENDAHULUAN}

Pada dasarnya tujuan dari investasi adalah untuk memperoleh tambahan pendapatan. Investor menginvestasikan aset yang dimilikinya dengan harapan dapat memperoleh keuntungan yang berlipat daripada sebelumnya. Keuntungan yang diharapkan oleh investor sejalan dengan arah suatu perusahaan untuk meningkatkan keuntungannya. Pada era saat ini, terdapat berbagai jenis cara untuk mewujudkan tujuan perusahaan salah satunya adalah menjadikan perusahaan go public. Guna memperoleh keuntungan investor dapat menginvestasikan dananya pada saham suatu perusahaan yang go public. Namun begitu, berinvestasi pada saham merupakan hal yang berisiko. Keuntungan dan risiko yang dihadapi berbanding lurus, apabila investor memperoleh keuntungan yang cukup tinggi maka investor tersebut akan menghadapi risiko yang cukup tinggi pula (Putriani, 2014).

Salah satu alat untuk memprediksi return dan megukur kinerja perusahaan adalah dengan menganalisis harga saham (Dewi, 2019). Terdapat dua jenis analisis yang dapat digunakan yaitu analisis fundamental dan analisis teknikal, analisis fundamental didasarkan pada kondisi keuangan suatu perusahaan sehingga nilai saham dapat dijelaskan oleh kinerja keuangan perusahaan dan informasi mengenai kinerja keuangan perusahaan tercermin dalam laporan keuangan yang membantu investor untuk mengambil keputusan dalam hal menempatkan sumber dayanya pada perusahaan tersebut (Anwaar, 2016). Kedua yaitu analisis teknikal, analisis ini didasarkan atas pengamatan terhadap data harga saham secara historis yang kemudian dijadikan sebagai awalan untuk memprediksi harga saham di masa mendatang (Halim, 2005:5). Di antara dua jenis analisis tersebut, analisis fundamental merupakan analisis utama yang dapat digunakan untuk menganalisis harga saham (Tryfino, 2009:18). Hal tersebut sejalan dengan penelitian oleh Endri (2018) yang menyatakan bahwa analisis fundamental lebih umum digunakan oleh investor.

Sebagai alat ukur kinerja keuangan perusahaan, analisis fundamental yang salah satunya terdiri atas analisis rasio merupakan alat paling dasar yang dapat digunakan untuk menganalisis dan menginterpretasikan isi dari laporan keuangan perusahaan. Analis menggunakan analisis rasio untuk mengetahui kekuatan dan kelemahan perusahaan meskipun masih terdapat banyak faktor di luar analisis fundamental yang dapat dijadikan pedoman untuk menganalisis kinerja perusahaan (Din, 2017). Investor yang selektif memiliki beragam kriteria sebelum menyeleksi perusahaan tempat investasinya. Bursa Efek Indonesia (BEI) telah mengelompokkan perusahaan dengan kriteria-kriteria yang diharapkan investor ke dalam indeks LQ45. Perusahaan yang masuk ke dalam kategori indeks tersebut dipantau perkembangannya secara rutin serta dievaluasi urutan pergerakan sahamnya untuk menjamin kewajaran pemilihannya. Perusahaan yang tergolong ke dalam indeks LQ45 memiliki kriteria kondisi keuangan yang baik dan prospek yang baik di masa depan. Jumlah emiten yang tergolong ke dalam indeks LQ45 terdiri atas 45 emiten yang posisinya dapat berubah-ubah selama kurun waktu 6 bulan.

Salah satu perusahaan yang terindeks LQ45 periode 2016-2018 adalah perusahaan dengan kode MYRX atau Hanson International Tbk. merupakan perusahaan yang bergerak pada sub sektor property and real estate. Nilai likuiditas 
perusahaan yang diproksikan dengan current ratio selama tahun 2016-2018 berada di bawah seratus persen. Nilai likuiditas yang rendah dapat mengindikasikan bahwa perusahaan memiliki kesulitan dalam melunasi kewajiban jangka pendeknya. Selain itu pada tahun 2016 nilai ROE perusahaan sebesar -1,220, nilai ROE yang rendah menandakan perusahaan tidak efektif dalam mengelola modal sendiri untuk menghasilkan laba. Namun begitu, secara berturut-turut dari tahun 2016-2018 nilai DER perusahaan masih berada di bawah 1, hal ini berarti perusahaan dalam keadaaan sehat secara keuangan dari segi debt to equity ratio. Kondisi fundamental sedemikian rupa tidak memperlemah posisi MYRX dalam indeks LQ45.

Likuiditas mengukur kemampuan perusahaan memenuhi kewajiban jangka pendeknya dengan didasarkan pada aktiva lancar perusahaan yang relatif terhadap utang lancarnya (Hanafi, 2009:74). Likuiditas yang rendah dapat mengindikasikan bahwa perusahaan kesulitan dalam memenuhi kewajiban jangka pendeknya dengan menggunakan aktiva lancarnya, namun likuiditas yang terlampau tinggi dapat mengurangi laba yang dihasilkan perusahaan karena terdapat banyak dana yang terikat pada aset perusahaan (Pramana, 2017). Umunya likuiditas dapat diukur dengan current ratio dengan membandingkan aktiva lancar terhadap utang lancar. Apabila nilai CR perusahaan berada di bawah seratus persen maka artinya perusahaan mengalami kesulitan keuangan (Kuranta, 2016).

Kegiatan operasional perusahaan dalam menghasilkan laba dapat dijelaskan oleh rasio profitabilitas, kemudian laba merupakan cerminan utama yang dapat menggambarkan kinerja perusahaan (Raningsih, 2015). Dalam mengukur profitabilitas perusahaan dapat digunakan ROE (Return on Equity). Melalui rasio ini dapat diketahui seberapa efektif pengelolaan modal sendiri yang dimiliki perusahaan dalam rangka menghasilkan laba (Suandewi, 2016). Dada (2016) dalam penelitiannya menemukan bahwa, ROE memberikan gambaran kenaikan arus kas atas aktivitas operasi perusahaan dengan mengelola modal sendiri perusahaan. Secara mendalam ROE memperhitungkan perbandingan antara laba bersih dikurangkan dengan dividen saham preferen dengan rata-rata saham biasa (Hanafi, 2009:177). ROE mencerminkan seberapa besar kemampuan perusahaan dalam menghasilkan keuntungan dengan menggunakan modal sendiri (Carlo, 2014).

Rasio leverage menunjukkan seberapa besar perusahaan dibiayai oleh utang, jadi semakin tinggi tingkat rasio leverage suatu perusahaan maka semakin besar risiko yang dihadapi perusahaan tersebut dalam melunasi utang-utangnya (Raningsih, 2015). Dalam penelitian ini rasio leverage diproksikan dengan DER (Debt to Equity), rasio ini menunjukkan perbandingan antara total kewajiban dengan total seluruh ekuitas (modal sendiri) yang digunakan untuk membayar utang (Prasetyo, 2018). Kebijakan pengelolaan utang yang dilakukan oleh perusahan merupakan salah satu dasar yang digunakan oleh investor untuk mengambil keputusan investasi.

Secara konsep, perusahaan terindeks LQ45 memiliki kapitalisasi pasar yang baik. Kapitalisasi pasar mencerminkan kemampuan perusahaan dalam mengembangkan potensi yang dimiliki serta menurunkan risiko yang dihadapi (Ardiansyah, 2013). Nilai kapitalisasi pasar yang tinggi akan mempengaruhi 
lamanya investor dalam menahan kepemilikan sahamnya pada suatu perusahaan (Silviyani, 2014). Kapitalisasi pasar merupakan salah satu komponen yang membedakan perusahaan LQ45 dengan non LQ45 dimana perusahaan LQ45 berdirikan atas perusahaan dengan kapitalisasi pasar tertinggi.

Berdasarkan latar belakang masalah yang telah diuraikan di atas, maka dapat dirumusakan masalah penelitian adalah: 1) Adakah perbedaan kinerja perusahaan dari segi likuiditas antara perusahaan yang terindeks LQ45 dengan non LQ45? 2) Adakah perbedaan kinerja perusahaan dari segi profitabilitas antara perusahaan yang terindeks LQ45 dengan non LQ45? 3) Adakah perbedaan kinerja perusahaan dari segi leverage antara perusahaan yang terindeks LQ45 dengan non LQ45. Berdasarkan rumusan masalah, maka tujuan dari penelitian ini adalah: 1) Untuk mempelajari atau mengetahui secara empiris mengenai perbedaan kinerja perusahaan dari segi likuiditas antara perusahaan yang terindeks LQ45 dengan non LQ45, 2) Untuk mempelajari atau mengetahui secara empiris mengenai perbedaan kinerja perusahaan dari segi profitabilitas antara perusahaan yang terindeks LQ45 dengan non LQ45, 3) Untuk mempelajari atau mengetahui secara empiris mengenai perbedaan kinerja perusahaan dari segi leverage antara perusahaan yang terindeks LQ45 dengan non LQ45.

Penelitian ini diharapkan mampu memberikan manfaat baik secara teoretis maupun praktis. Secara teoretis penelitian ini diharapkan mampu memberikan kontribusi bagi pengembangan ilmu dan teori serta memverifikasi teori yang dirujuk dalam penelitian ini yaitu teori sinyal dan teori trade-off dalam kaitannya dengan kinerja perusahaan. secara praktis, hasil penelitian ini diharapkan mampu memberikan kontribusi pemikiran mengenai analisis kinerja perusahaan bagi investor dan calon investor serta memberikan tambahan referensi bagi penelitian lainnya yang menggunakan objek serupa.

Teori dasar yang digunakan dalam penelitian ini adalah teori sinyal. Menurut Brigham \& Houston (2014:184) isyarat atau signal dihasilkan oleh tindakan manajemen dalam mengelola perusahaan yang mampu memberikan informasi bagi investor mengenai kondisi perusahaan saat ini maupun mendatang. Sinyal ini dapat berupa informasi mengenai pengelolaan operasional perusahaan yang secara berkelanjutan dapat memberikan hasil bagi pemegang saham atau investor. Informasi yang dikeluarkan perusahaan merupakan hal penting karena pada dasarnya informasi mengandung keterangan, catatan dan gambaran, baik untuk keadaan di masa lalu, masa sekarang, dan di masa depan mengenai kondisi peruasahaan dan dampaknya terhadap pihak - pihak terkait. Model sinyal struktur keuangan menjelaskan bahwa perusahaan dengan kualitas yang baik akan berupaya menggunakan struktur modal untuk menciptakan sinyal bagi pengguna. Sinyal tersebut mengandung informasi yang menggambarkan bahwa perusahaan memiliki kualitas yang baik dibandingkan dengan perusahaan lainnya. Berdasarkan sinyal tersebut perusahaan berupaya mencapai hasil berupa keseimbangan pemisahan (separating equilibrium) dengan tujuan pengguna laporan keuangan dapat membedakan baik atau buruknya kualitas setiap perusahaan yang tercermin dari keputusan perusahaan dalam menentukan struktur modalnya (Gumanti, 2009). 
Trade off theory yang diungkapkan oleh Myers (2001), menyatakan bahwa suatu perusahaan akan menambah utang hingga mencapai titik tertentu dimana penghematan pajak (tax shield) yang berasal dari adanya tambahan utang mencapai titik keseimbangan dengan biaya kesulitan (financial distress). Biaya kesulitan yang dimaksud menyangkut biaya kebangkrutan dan biaya agensi yang meningkat dikarenakan menurunnya kredibilitas perusahaan. Trade-off theory memiliki hubungan dengan tingkat leverage suatu perusahaan. Teori ini memiliki implikasi bahwa manajer akan berpikir dalam kerangka trade-off dimana manajer akan meminimalkan biaya pajak dengan menambah utang. Berkaitan dengan hal tersebut, perusahaan dengan profitabilitas yang tinggi akan mengurangi pajak melalui peningkatan utang. Teori trade off mendasari adanya hubungan antara profitabilitas suatu perusahaan dengan leverage. Perusahaan menambah leverage guna meningkatkan profitabilitas perusahaan dengan berpedoman pada titik tertentu. Berdasarkan konsep tersebut dalam menilai kinerja suatu perusahaan perlu didasarkan pada banyak aspek penting yang apabila dinilai hanya dari satu sisi maka tidak akan relevan. Leverage yang tinggi tidak secara absolut menandakan suatu perusahaan memiliki kinerja yang tidak baik, melainkan dalam beberapa kondisi leverage yang tinggi terkadang dapat meningkatkan profitabilitas suatu perusahaan (Aharon, 2019).

Kinerja perusahaan dapat mencerminkan kondisi keuangan perusahaan. pengukuran kinerja perusahaan dapat dilakukan dengan memanfaatkan analisis rasio keuangan. Melalui pengukuran kinerja dapat diketahui tingkat keefektifan dan keefisienan pengelolaan manajemennya. Prestasi kerja perusahaan dapat terbaca melalui output perusahaan. Prestasi yang baik tentunya akan menciptakan nilai yang baik di mata investor hal ini juga berlaku sebaliknya (Kamajaya, 2019). Kinerja perusahaan dalam penelitian ini diukur dengan analisis rasio likuiditas, profitabilitas, dan leverage. Ketiga rasio tersebut dapat dijadikan sebagai alat untuk mengukur kinerja perusahaan di luar faktor makro yang terjadi secara global (Chytis, 2018).

Menurut Prabasari (2018), likuiditas mencerminkan kemampuan perusahaan dalam memenuhi kewajibannya dengan memanfaatkan aset yang dimilikinya, atau dapat diartikan pula dengan kemampuan perusahaan melunasi kewajiban lancarnya dengan menggunakan aset lancarnya. Rendahnya nilai likuiditas suatu perusahaan menandakan ketidakmampuan perusahaan dalam melunasi kewajibannya. Ketika suatu perusahaan tidak mampu memenuhi kewajibannya maka perusahaan tersebut akan memperoleh beban tambahan yang apabila jumlahnya terlampau tinggi selanjutnya dapat mempengaruhi profitabilitas perusahaan.

Semakin tinggi nilai likuiditas perusahaan maka semakin tinggi pula peluang perusahaan untuk memenuhi kewajibannya. Hal ini dapat menumbuhkan kepercayaan bagi pemegang saham untuk berinvestasi pada perusahaan sehingga harga saham akan naik dan meningkatkan return saham perusahaan. Hal ini mengindikasikan bahwa investor atau pemegang saham akan memperoleh return yang lebih tinggi (Putra, 2016). Proporsi CR yang baik dapat dijadikan sebagai salah satu kriteria yang mencerminkan bahwa perusahaan memiliki kinerja yang baik. Berdasarkan teori sinyal perusahaan dengan kondisi likuiditas yang baik dapat menghasilkan sinyal positif bagi investor untuk 
menilai kinerja perusahaan. Penelitian oleh (Nugroho, 2018) menyatakan bahwa terdapat perbedaan dari segi rasio likuiditas antara perusahaan yang terindeks LQ45 dengan perusah non LQ45. Berdasarkan kajian teori dan penelitian sebelumnya, maka dapat dirumuskan hipotesis pertama sebagai berikut.

$\mathrm{H}_{1}$ : Terdapat perbedaan kinerja dari segi likuiditas perusahaan antara perusahaan yang terindeks LQ45 dan non LQ45.

Profitabilitas merupakan rasio yang mencerminkan kemampuan suatu perusahaan dalam menghasilkan keuntungan. Profitabilitas memiliki peranan yang sangat penting dalam menjaga kelangsungan perusahaan jangka panjang karena profitabilitas menjelaskan baik buruknya prospek perusahaan ke depannya. Menurut Wiagustini (2014:86) profitabilitas adalah kemampuan perusahaan dalam menghasilkan laba atau dapat pula diartikan sebagai tingkat efektivitas pengelolaan manajemen perusahaan yang dapat diukur dari modal sendiri maupun dari total dana yang diinvestasikan pada perusahaan.

Kebijakan investor untuk berinvestasi dalam suatu perusahaan dipengaruhi oleh profitabilitas perusahaan tersebut. Investor akan tertarik untuk menanamkan modalnya dengan menganalisis kemampuan perusahaan dalam menghasilkan laba yang dapat tercermin dari analisis terhadap profitabilitas perusahaan, sehingga semakin tinggi tingkat profitabilitas perusahaan akan semakin menarik bagi investor namun apabila nilai profitabilitas perusahaan cukup rendah akan menyebabkan investor untuk menarik dananya yang berujung pada penurunan permintaan terhadap saham (Ali, 2016).

Informasi mengenai nilai ROE perusahaan dapat menjadi sinyal bagi pengguna mengenai kondisi keuangan perusahaan. Teori sinyal dapat menjelaskan kondisi perusahaan yang tercermin dari struktur modalnya untuk mengkomunikasikan keadaan perusahaannya guna membedakan kualitasnya dari perusahaan lainnya, perusahaan LQ45 memiliki nilai profitabilitas yagng lebih baik bila dibandingkan dengan non LQ45 sehingga akan mengahasilkan sinyal positif bagi investor dan pihak terkait lainnya. Menurut Ali (2016) perusahaan dengan kinerja yang baik cenderung menghasilkan laba yang tinggi. Penelitian yang dilakukan oleh (Nugroho, 2018) menyatakan bahwa terdapat perbedaan antara perusahaan terindeks LQ45 dengan non LQ45 dari segi profitabillitas. Berdasarkan kajian teori dalam penelitian ini maka dapat dirumuskan hipotesis kedua dalam penelitian ini sebagai berikut.

$\mathrm{H}_{2}$ : Terdapat perbedaan kinerja dari segi profitabilitas perusahaan antara perusahaan yang terindeks LQ45 dan non LQ45.

Perusahaan menjalankan operasinya memerlukan modal sebagai penggerak aktivitasnya. Utang dapat melengkapi modal dan memberikan kesempatan bagi suatu perusahaan untuk meningkatkan performanya (Yang, 2016). Istilah utang sering dihubungkan dengan kata leverage, secara teori leverage dapat menaikkan return yang diharapkan investor. Perusahaan skala besar biasanya memiliki tingkat leverage yang tinggi, namun tingkat leverage yang terlampau tinggi dapat menyebabkan bertambahnya tingkat risiko investasi yang berarti potensi loss dan gain menjadi meningkat. Kondisi tersebut disebut dengan leverage effect (Andersson, 2016).

Leverage yang rendah dapat mengurangi risiko yang dihadapi oleh investor. perusahaan dengan leverage yang rendah umumnya membiayai operasionalnya 
dengan mengandalkan modal saham ataupun modal sendiri sehingga perusahaan terbebas dari beban tetap (Iqbal \& Usman, 2018). Peningkatan utang perusahaan akan berimbas pada menurunnya solvabilitas perusahaan yang kemudian akan berakibat pada menurunnya return saham yang akan diperoleh (Purwitajati, 2016). Penggunaan modal sendiri untuk membiayai perusahaan akan memangkas beban tetap akibat utang sehingga dapat meningkatkan profitabilitas perusahaan (Mocnik \& Sirec, 2015). Utang jangka panjang maupun utang jangka pendek dapat mengurangi kinerja perusahaan, apabila utang perusahaan jumlahnya lebih besar dari total modal perusahaan maka kinerja perusahaan tidak akan berjalan baik sehingga manajer perlu memperhitungkan dengan baik proporsi leverage perusahaan (Awais, et al., 2016). Menurut Rabbani (2015) kenaikan utang akan menurunkan performa perusahaan dan secara tidak langsung dapat menurunkan laba yang dihasilkan oleh perusahaan.

Hal tersebut bertentangan dengan penelitian oleh Nguyen (2019) yang menyatakan bahwa bertambahanya utang perusahaan memiliki pengaruh pada meningkatnya penjualan perusahaan yang berarti meningkatnnya utang perusahaan diikuti dengan keuntungan yang diperoleh oleh perusahaan. Huang (2006) dalam penelitiannya menemukan bahwa sebagian besar perusahaan khususnya di China menggunakan utang dalam jumlah yang cukup tinggi untuk membiayai perusahaanya sehingga dapat meningkatkan keuntungannya. Pada beberapa kondisi leverage yang tinggi dapat mengandung sinyal bahwa perusahaan optimis dapat meningkatkan laba dengan memanfaatkan utang serta yakin mampu melunasi biaya yang timbul akibat penambahan utang tersebut. Pada beberapa kondisi leverage yang tinggi pula dapat mengandung sinyal bahwa perusahaan optimis dapat meningkatkan laba dengan memanfaatkan utang tersebut dan mampu meluansi biaya yang timbul dari adanya utang tersebut (Ahmad, 2015).

Teori sinyal dengan model financial structure yang dinyatakan oleh Brander \& Lewis, (2009) menjelaskan bahwa nilai leverage perusahaan dapat menggambarkan informasi mengenai kualitas perusahaan. Leverage dapat mengkomunikasikan beberapa hal, nilai leverage yang tinggi menunjukkan struktur modal perusahaan dibiayai oleh utang yang tinggi dalam hal ini perusahaan berupaya menunjukkan kepercayaan dirinya bahwa perusahaan memiliki sumber daya yang cukup untuk digunakan melunasi biaya yang timbul dari utang tersebut. Selain hal tersebut nilai leverage yang tinggi dapat mengandung sinyal bahwa perusahaan berupaya menekan perusahaan lain agar tidak mampu mencontohnya, dalam hal ini perusahaan berupaya menciptakan batas pemisah dari segi kualitas dengan perusahaan lainnya. Dapat disimpulkan bahwa utang mencerminkan tingkat risiko yang dihadapi oleh suatu perusahaan. Menurut Polakitan (2015), perusahaan LQ45 memiliki risiko keuangan yang lebih rendah bila dibandingkan dengan perusahaan non LQ45. Berdasarkan kajian teori dan penelitian sebelumnya maka dapat dirumuskan hipotesis ketiga sebagai berikut.

$\mathrm{H}_{3}$ : Terdapat perbedaan kinerja dari segi leverage perusahaan antara perusahaan yang terindeks LQ45 dan non LQ45. 


\section{METODE PENELITIAN}

Penelitian ini menggunakan metode kuantitatif berbentuk komparatif. Desain penelitian ini menggunakan pendekatan komparatif untuk menganalisis perbedaan kinerja perusahaan antara perusahaan yang terindeks LQ45 dan non LQ45. Hipotesis dalam penelitian ini menggunakan pengujian independent sample $t$ test. Uji ini digunakan untuk menguji beda dua rata-rata untuk sampel yang independen. Penelitian ini dilakukan di Bursa Efek Indonesia melalui website resmi yaitu www.idx.co.id dan mengunduh data sekunder berupa laporan keuangan perusahaan yang terindeks LQ45 dan non LQ45 periode 2016-2018. Objek penelitian ini adalah kinerja perusahaan. Penelitian ini menggunakan variabel tunggal yaitu kinerja perusahaan yang dijelaskan dengan likuiditas, profitabilitas, dan leverage.

Pada penelitian ini likuditas diproksikan dengan current ratio (CR) yaitu rasio yang membandingkan antara aset lancar suatu perusahaan dengan kewajiban lancarnya. Adapun current ratio dapat dirumuskan sebagai berikut.

$$
\mathrm{CR}=\frac{\text { Aset Lancar }}{\text { Kewajiban Lancar }} \times 100 \% \text {. }
$$

Pada penelitian ini profitabilitas diproksikan dengan ROE (Return On Equity) yang membandingkan antara laba setelah pajak (EAT) dengan ekuitas perusahaan. ROE dapat diperhitungakan dengan rumus sebagai berikut.

$\mathrm{ROE}=\frac{\text { Laba Bersih }}{\text { Total Ekwitas }} \times 100 \%$

Rasio leverage mengukur kemampuan perusahaan dalam memenuhi seluruh kewajibannya baik jangka pendek maupun jangka panjang. Dalam penelitian ini, leverage diproksikan dengan DER (Debt to Equity). DER dapat dirumuskan sebagai berikut.

DER $=\frac{\text { Total Liabilitas }}{\text { Total Modal Sendiri }}$

Populasi dalam penelitian ini adalah seluruh perusahaan yang terindeks LQ45 dan non LQ45 yang yang tergabung dalam sub sektor atau industri sejenis dengan perusahaan yang terindeks LQ45 pada periode pengamatan yang terdaftar di Bursa Efek Indonesia periode 2016-2018. Sampel dalam penelitian ini yaitu bagian dari perusahaan yang terdaftar dalam indeks LQ45 dan non LQ45 pada periode 2016-2018 yang memenuhi kriteria. Metode penentuan sampel yang digunakan dalam penelitian ini adalah metode non probability sampling dengan teknik purposive sampling. Pengambilan sampel pada penelitian ini didasarkan atas beberapa kriteria seperti Perusahaan yang terindeks LQ45 dan non LQ45 yang bergerak pada sektor non keuangan. Hipotesis dalam penelitian ini diuji menggunakan uji dua sampel tidak berpasangan. Uji independent $t$-test digunakan untuk menguji hipotesis alternative apabila diketahui data berdistribusi normal, namun bila data tidak berdistribusi normal maka hipotesis alternatif diuji menggunakan pengujian non parametric yaitu Mann-Whitney $U$ Test.

\section{HASIL DAN PEMBAHASAN}

Penelitian ini dilakukan pada perusahaan non LQ45 dan perusahaan terindeks LQ45 pada BEI periode tahun 2016-2018. Saham-saham indeks LQ45 dipilih karena berbagai alasan diantaranya, karena merupakan saham yang paling aktif 
diperdagangkan setiap hari bursa, terdiri dari 45 perusahaan dengan kapitalisasi pasar tertinggi dan likuiditas yang tinggi, serta lolos seleksi dengan berbagai kriteria penilaian oleh BEI. Sampel dalam penelitian ini dipilih berdasarkan kriteria yang sudah ditentukan atau melalui purposive sampling sehingga sampel yang digunakan dapat mewakili populasi sesuai dengan tujuan perusahaan. berdasarkan kriteria penentuan sampel maka dapat diperoleh hasil sebagai berikut.

\section{Tabel 1. Hasil Seleksi Pemilihan Sampel}

\begin{tabular}{llc}
\hline No & \multicolumn{1}{c}{ Keterangan } & Jumlah \\
\hline 1 & $\begin{array}{l}\text { Perusahaan non keuangan yang terdaftar di BEI pada tahun 2016- } \\
2018\end{array}$ & 597 \\
2 & $\begin{array}{l}\text { Perusahaan non LQ45 dengan kapitalisasi pasar yang rendah dan } \\
\text { tidak memuat data laproan keuangan yang diperlukan peneliti }\end{array}$ & $(459)$ \\
3 & $\begin{array}{l}\text { Perusahaan LQ45 dan Non LQ45 yang tidak menyajikan laporan } \\
\text { keuangan dengan lengkap }\end{array}$ & $(48)$ \\
$4 \quad \begin{array}{l}\text { Jumlah perusahaan terpilih sebagai sampel } \\
\text { Total sampel dalam tiga periode penelitian }\end{array}$ & 90 \\
Jumlah sampel yang digunakan selama tiga periode penelitian perusahaan \\
amatan
\end{tabular}

Sumber: Data Penelitian, 2020

Jumlah perusahaan yang terindeks LQ45 selama periode penelitian adalah sebesar 59 perusahaan yang terdiri atas berbagai macam sektor termasuk sektor keuangan/finansial. Jumlah sampel yang digunakan dalam penelitian ini adalah sebanyak 45 perusahaan yang terindeks LQ45 dan non LQ45 selama 3 periode pengamatan sehingga diperoleh 135 jumlah perusahaan amatan untuk masingmasing kelompok yang akan dibandingkan dan apabila dijumlahkan maka diperoleh total keseluruhan perusahaan amatan adalah sebesar 270 .

Penelitian ini telah menguji kenormalan data dengan metode KolmogorovSmirnov dan memperoleh nilai signifikansi masing-masing variabel yang terdiri atas current ratio, return on equity, dan debt to equity ratio secara berurutan sebesar 0,000, 0,001, dan 0,000 lebih kecil dari 0,05 sehingga dapat disimpulkan bahwa masing-masing variabel likuiditas, profitabilitas, dan leverage berdistribusi tidak normal.

Berdasarkan Tabel 1, diketahui nilai z-hitung untuk variabel likuiditas yang diproksikan dengan current ratio (CR) adalah sebesar -2,679 dengan nilai Sig. (2tailed) sebesar 0,007 lebih kecil dari tingkat signifikansi yang ditentukan yaitu 0,05. Dengan demikian, dapat disimpulkan bahwa $\mathrm{H}_{0}$ ditolak dan $\mathrm{H}_{1}$ diterima, yang berarti ada perbedaan rata-rata kinerja perusahaan dari segi likuiditas yang diproksikan dengan current ratio (CR) antara perusahaan yang terindeks LQ45 dengan non LQ45 di BEI.

Nilai z-hitung untuk variabel profitabilitas yang diproksikan dengan return on equity (ROE) adalah sebesar -2,132 dengan nilai Sig. (2-tailed) sebesar 0,033 lebih kecil dari tingkat signifikansi yang ditentukan yaitu 0,05. Dengan demikian, dapat disimpulkan bahwa $\mathrm{H}_{0}$ ditolak dan $\mathrm{H}_{2}$ diterima, yang berarti ada perbedaan rata-rata kinerja perusahaan dari segi profitabilitas yang diproksikan 
dengan return on equity (ROE) antara perusahaan yang terindeks LQ45 dengan non LQ45 di BEI.

Tabel 2. Mann-Whitney Test

\begin{tabular}{lccl}
\hline $\begin{array}{c}\text { Kinerja } \\
\text { Perusahan }\end{array}$ & $Z$ & Asymp.Sig. (2-tailed) & Keterangan \\
\hline CR & $-2,679$ & 0,007 & Signifikan \\
ROE & $-2,132$ & 0,033 & Signifikan \\
DER & $-2,715$ & 0,007 & Signifikan \\
\hline
\end{tabular}

Sumber: Data Penelitian, 2019

Nilai z-hitung untuk variabel leverage yang diproksikan dengan debt to equity ratio (DER) adalah sebesar -2,715 dengan nilai Sig. (2-tailed) sebesar 0,007 lebih kecil dari tingkat signifikansi yang ditentukan yaitu 0,05. Dengan demikian, dapat disimpulkan bahwa $\mathrm{H}_{0}$ ditolak dan $\mathrm{H}_{3}$ diterima, yang berarti ada perbedaan rata-rata kinerja perusahaan dari segi profitabilitas yang diproksikan dengan return on equity (ROE) antara perusahaan yang terindeks LQ45 dengan non LQ45 di BEI.

Hasil penelitian ini mendukung teori sinyal yang menyatkan bahwa perusahaan dengan kinerja yang baik akan menghasilkan informasi yang mengandung sinyal positif. Nilai likuiditas perusahaan LQ45 lebih tinggi dibandingkan dengan non LQ45 sehingga dapat menghasilkan sinyal positif bagi pengguna yang berujung pada bertahannnya perusahaan dalam indeks LQ45. Hasil penelitian ini juga mendukung penelitian yang dilakukan oleh (Nugroho, 2018) menyatakan bahwa terdapat perbedaan dari segi rasio likuiditas antara perusahaan yang terindeks LQ45 dengan perusah non LQ45.

Hasil ini mendukung teori sinyal yang menjelaskan bahwa tindakan yang diambil manajemen perusahaan dapat menjadi petunjuk bagi investor mengenai bagaimana manajemen memandang prospek perusahaan. Perusahaan berusaha menghasilkan sinyal positif kepada investor guna meningkatkan kredibilitasnya, dimana sinyal tersebut dapat diberikan melalui pengungkapan informasi akuntansi seperti laporan keuangan. Guna menghasilkan sinyal yang baik, perusahaan akan meningkatkan performanya sehingga dapat meningkatkan nilai perusahaan di mata investor. Dalam hal ini perusahaan LQ45 merupakan perusahaan dengan kualitas yang baik sehingga sinyal yang dihasilkanpun bersifat positif.

Hipotesis kedua $\left(\mathrm{H}_{2}\right)$ menyatakan terdapat perbedaan kinerja perusahaan dari segi profitabilitas antara perusahaan terindeks LQ45 dengan perusahaan non LQ45. Hasil penelitian ini mendukung penelitian yang dilakukan oleh (Nugroho, 2018) menyatakan bahwa terdapat perbedaan antara perusahaan terindeks LQ45 dengan non LQ45 dari segi profitabillitas. Nilai ROE perusahaan yang terindeks LQ45 yang lebih tinggi bila dibandingkan dengan perusahaan non LQ45 berarti bahwa perusahaan yang terindeks LQ45 lebih mampu mengelola modal sendiri yang dimilikinya untuk menghasilkan laba yang lebih tinggi. Hal ini juga mendukung teori sinyal dimana perusahaan dengan kinerja yang baik akan menghasilkan informasi yang dapat mengandung sinyal positif bagi pengguna laporan keuangan. 
Hipotesis ketiga $\left(\mathrm{H}_{3}\right)$ dari penelitian ini adalah terdapat perbedaan kinerja perusahaan dari segi leverage antara perusahaan terindeks LQ45 dengan non LQ45. Hasil penelitian ini mendukung penelitian oleh Polakitan (2015), perusahaan LQ45 memiliki risiko keuangan yang lebih rendah bila dibandingkan dengan perusahaan non LQ45. Hasil group statistics menunjukkan bahwa rata-rata nilai leverage yang diproksikan dengan debt to equtity (DER) perusahaan terindeks LQ45 lebih kecil dibandingkan dengan perusahaan non LQ45. Hal ini sesuai dengan penelitian yang dilakukan oleh Dewi (2019) yang menyatakan bahwa bertambahnya utang akan menurunkan nilai perusahaan, selain itu hasil mendukung penelitian oleh Mocnik (2015) yang menyatakan bahwa penggunaan modal sendiri dapat memangkas biaya utang yang ada. Hasil penelitian tersebut mendukung teori sinyal yang menjelaskan sinyal merupakan suatu tindakan yang dilakukan oleh manajemen perusahaan, yang dapat memberikan petunjuk kepada investor tentang bagaimana manajemen memandang prospek perusahaan, kinerja perusahaan yang baik akan menghasilkan sinyal positif kepada pengguna laporan keuangan sehingga dapat memperkuat nilai perusahaan di kalangan investor. Dalam hal ini perusahaan LQ45 memiliki kinerja yang baik sehingga mampu mempertahankan kapitalisasi pasar dan likuiditas sahamnya (Brigham \& Houston, 2014:184). Nilai DER yang tinggi menunjukkan bahwa perusahaan memiliki utang yang besar. Selama ekonomi dalam keadaan yang sulit atau suku bunga tinggi, perusahaan dengan tingkat DER yang tinggi akan mengalami masalah keuangan. Kondisi tersebut dapat menurunkan profitabilitas perusahaan. Hal ini dapat dijadikan sinyal bagi investor untuk memutuskan melakukan investasi atau tidak dalam suatu perusahaan yang sedang mengalami situasi tersebut.

Sebaliknya hasil penelitian ini telah mengkontra teori trade-off yang menjelaskan bahwa suatu perusahaan akan menambah utang hingga mencapai titik tertentu dimana jumlahnya sudah melebihi menfaat yang diperoleh perusahaan. Trade off theory mendasari adanya hubungan antara profitabilitas suatu perusahaan dengan leverage. Perusahaan menambah leverage dengan tujuan untuk meningkatkan profit. Berdasarkan hasil yang ditunjukkan dari group statistics maka diketahui bahwa rata-rata jumlah DER perusahaan terindeks LQ45 lebih rendah apabila dibandingkan dengan perusahaan non LQ45 diikuti pula oleh hasil yang menunjukkan bahwa nilai rata-rata ROE perusahaan terindeks LQ45 lebih besar dibandingkan dengan perusahaan non LQ45 dimana dapat dikatakan bahwa rendahnya rata-rata DER pada perusahaan terindeks LQ45 diikuti dengan tingginya rata-rata ROE pada kelompok perusahaan tersebut. Hal ini berlaku juga bagi kelompok perusahaan non LQ45 dimana nilai rata-rata DER yang diikuti tidak menghasilkan profit yang lebih tinggi.

\section{SIMPULAN}

Berdasarkan hasil penelitian yang diperoleh melalui pengujian statistik serta pembahasan, maka dapat disimpulkan beahwa: terdapat perbedaan kinerja perusahaan dari segi likuiditas antara perusahaan terindeks LQ45 dengan non LQ45. Perusahaan yang terindeks LQ45 memiliki nilai likuiditas yang lebih 
tinggi apabila dibandingakan dengan peusahaan non LQ45. Tinggi atau rendahnya masing-masing nilai rata-rata antara kedua kelompok perusahaan tersebut dapat menunjang keputusan investasi bagi investor.

Terdapat perbedaan kinerja perusahan dari segi profitablitas antara perusahaan terindeks LQ45 dengan perusahaan non LQ45. Perusahaan yang terindeks LQ45 memiliki rata-rata nilai ROE yang lebih tinggi dibandingkan dengan perusahaan non LQ45. Hal ini berarti perusahaan yang terindeks LQ45 memiliki kemampuan mengelola modal sendiri untuk menghasilkan laba yang lebih produktif dibandingkan dengan perusahaan non LQ45.

Terdapat perbedaan kinerja perusahaan dari segi leverage antara perusahaan terindeks LQ45 dengan non LQ45. Perusahaan yang terindeks LQ45 memiliki rata-rata nilai yang lebih rendah dibandingkan dengan perusahaan non LQ45. Tinggi rendahnya nilai leverage yang diproksikan dengan DER dapat mencerminkan tinggi rendahnya risiko yang dihadapi oleh investor, sehingga baik buruknya dampak dari tingkat DER dari kedua kelompok perusahaan ini diharapkan mampu menunjang keputusan pengguna laporan keuangan dengan mengetahui kinerja perusahaan dari segi leverage.

Berdasarkan hasil yang diperoleh dari pembahasan statistik dan simpulan tersebut, maka saran yang dapat diberikan adalah bagi penelitian selanjutnya dapat memperpanjang periode penelitian agar hasil penelitian selanjutnya dapat menunjukkan hasil yang lebih akurat. Selain itu, peneliti selanjutnya dapat memfokuskan penelitian pada satu industri atau pada satu sub sektor dengan memperhatikan siklus usaha masing-masing industri guna memperoleh hasil analisis kinerja yang tepat dan akurat.

\section{REFERENSI}

Aharon, D. Y., \& Yagil, Y. (2019). The Impact of Financial Leverage on Shareholders' Systematic Risk. Sustainability (Switzerland), 11(23), 175-188. https:// doi.org/10.3390/su11236548

Ahmad, N., Salman, A., \& Shamsi, A. F. (2015). Impact of Financial Leverage on Firms ' Profitability : An Investigation from Cement Sector of Pakistan. Research Journal Of Finance And Accounting, 6(7), 75-81.

Ali, M. (2016). Pengaruh Profitabilitas Terhadap Return Saham pada Perusahaan Badan Usaha Milik Negara (BUMN) yang Terdaftar Di Bursa Efek Indonesia (Bei) Periode 2010-2014 (Vol. 2014).

Andersson, M. (2016). The Effects of Leverage on Stock Returns. Economics and Management Journal of Lund University, 1-47.

Anwaar, M. (2016). Impact of Firms' Performance on Stock Returns (Evidence from Listed Companies of Ftse-100 Index London, UK). Global Journal of Management and Business Research: Accounting and Auditing, 16(1).

Ardiansyah. (2013). Analisis Pengaruh Faktor Fundamental dan Nilai Kapitalisasi Pasar terhadap Return Saham. Jurnal Ilmiah Mahasiswa FEB Universitas Brawijaya, 1(2).

Awais, M., Iqbal, W., \& Khursheed, A. (2016). Impact of Capital Structure on The Firm Performance : Impact of Capital Structure on The Firm Performance : Comprehensive Study of Karachi Stock Exchange. Scienstific International (Lahore), 28(1), 501-507. 
Brander, J. A., \& Lewis, T. R. (2009). Oligopoly and Financial Structure: The Limited Liability Effect. Cournot Oligopoly, 421-444. https:/ / doi.org/10.1017/cbo9780511528231.025

Brigham, \& Houston. (2014). Dasar-Dasar Manajemen Keuangan (11th ed.). Jakarta: Salemba Empat.

Carlo, M. A. (2014). Pengaruh Return on Equity, Dividend Payout Ratio, dan Price to Earnings Ratio pada Return Saham. E-Jurnal Akuntansi, 7(1), 150164.

Chytis, E., Tasios, S., \& Arnis, N. (2018). Factors Affecting Firm Performance in Periods of Financial Crisis : Evidence from the Listed on the Athens Stock Exchange Food Companies. 12(October).

Dada, A. O., \& Ghazali, Z. B. (2016). The Impact of Capital Structure on Firm Performance: Empirical Evidence from Nigeria. IOSR Journal of Economics and Finance, 07(04), 23-30. https://doi.org/10.9790/5933-0704032330

Dewi, I. A. L. (2019). Pengaruh Inflasi, Profitabilitas dan Ukuran Perusahaan pada Return Saham Perusahaan Terindeks LQ45. 27, 1120-1143. https:// doi.org/10.24843/EJA.2019.v27.i02.p11

Din, W. U. (2017). Stock Return Predictability with Financial Ratios: Evidence from PSX 100 Index Companies. SSRN Electronic Journal, 6 (3), 269(March). https:// doi.org/10.2139/ssrn.3077890

Endri. (2018). Factors Determine Stock Return of Livestock Feed Companies : Common Effect Model Analysis. International Journal of New Technology and Research (IJNTR), 4(5), 106-113.

Gumanti, T. A. (2009). Teori Sinyal dalam Manajemen Keuangan. Manajemen Dan Usahawan Indonesia, (September), 1-29.

Halim, A. (2005). Analisis Investasi (Edisi Dua). Jakarta: Salemba Empat.

Hanafi, M. M. \& A. H. (2009). Laporan Analisis Keuangan. Yogyakarta: UPP STIM YKPN.

Huang, G., \& Frank M. Song. (2006). The Determinants of Capital Structure Evidence from China. China Economic Review, Vol 17(1), 14-36. https:// doi.org/10.1016/j.chieco.2005.02.007

Iqbal, U., \& Muhammad Usman. (2018). Impact of Financial Leverage on Firm Performance Textile Composite Companies of Pakistan. SEISENSE Journal of Management, 1(2), 71-78. https:// doi.org/10.33215/sjom.v1i2.13

Kamajaya, I. W. D. P., \& Dwija Putri, I. G. A. M. A. (2019). Pengaruh Pertumbuhan Perusahaan, Kepemilikan Manajerial dan Kebijakan Dividen Pada Kinerja Perusahaan Manufaktur di BEI. E-Jurnal Akuntansi, 26, 997. https://doi.org/10.24843/eja.2019.v26.i02.p06

Kuranta, S. S. (2016). Analisis Tingkat Likuiditas Pada PT. Telekomunikasi Indonesia Tbk. Jurnal Administrasi BIsnis, 1-7.

Mocnik, D., \& Karin Sirec. (2015). Determinants of A Fast-Growing Firm ' s Profits : Empirical Evidence for Slovenia. Scientific Annals of Economics and Bussines, 62(1), 37-54. https:/ / doi.org/10.1515/aicue-2015-0003

Myers, S. C. (2001). Capital structure. Journal of Economic Perspectives, 15(2), 81102. https:// doi.org/10.4337/9781785363528.00012

Nguyen, Ho, \& Vo. (2019). An Empirical Test of Capital Structure Theories for the Vietnamese Listed Firms. Journal of Risk and Financial Management, 12(3), 
148. https:// doi.org/10.3390/jrfm12030148

Nugroho, M. N. (2018). Financial Ratio Analysis that Distinguishes Company Shares Indexed in LQ45 and the Non-LQ45 on the Indonesia Stock Exchange (Bursa Efek Indonesia). Archives of Business Research, 6(11), 208-224. https:// doi.org/10.14738/abr.611.5733

Polakitan, C. D. (2015). Analisis Komparasi Risiko Saham LQ45 Dan Non LQ45 pada Beberapa Sub Sektor Perusahaan yang Terdaftar Di Bursa Efek Indonesia (BEI). Jurnal Riset Bisnis Dan Manajemen, 3(1), 61-72.

Prabasari, N. T. (2018). Pengaruh Likuiditas terhadap Return Saham dan Profitabilitas pada Perusahaan Property dan Real Estate yang Terdaftar di Bursa Efek Indonesia. Jurnal Ekonomi Universitas Islam Indonesia, 1-10. Retrieved from https://dspace.uii.ac.id/handle/123456789/6193

Pramana, I. B. A., \& Badera, I. (2017). Analisis Faktor-Faktor yang Mempengaruhi Risiko Investasi Saham. E-Jurnal Akuntansi, 18(3), 1860-1887.

Prasetyo, A. (2018). Pengaruh Kinerja Keuangan dan Ukuran Perusahaan terhadap Return Saham (Studi Kasus pada Perusahaan Sektor Property, Real Estate dan Konstruksi Bangunan yang Terdaftar di BEI Tahun 20132015). Skripsi, 2.

Purwitajati, E., \& Dwiana Putra, I. (2016). Pengaruh Debt to Equity Ratio Pada Return Saham dengan Ukuran Perusahaan sebagai Pemoderasi. E-Jurnal Akuntansi, 15(2), 1086-1114.

Putra, I. M. G. D., \& I Made Dana. (2016). Pengaruh Profitabilitas, Leverage, Likuiditas dan Ukuran Perusahaan terhadap Return Saham Perusahaan Farmasi di BEI. E-Jurnal Manajemen Universitas Udayana, 5(11), 6825-6850.

Putriani, N., \& Sukartha, I. (2014). Pengaruh Arus Kas Bebas dan Laba Bersih pada Return Saham Perusahaan LQ-45. E-Jurnal Akuntansi, 6(3), 390-401.

Rabbani, M. (2015). Impact of Financial Leverage on Pakistani Firms. Journal of Poverty, Investment and Development, 15, 15-22.

Raningsih, N., \& Dwiana Putra, I. (2015). Pengaruh Rasio-Rasio Keuangan dan Ukuran Perusahaan pada Return Saham. E-Jurnal Akuntansi, 13(2), 582-598.

Silviyani, N. L. N. T., Sujana, E., \& Adiputra, I. M. P. (2014). Pengaruh Likuiditas Perdagangan Saham dan Kapitalisasi Pasar terhadap Return Saham Perusahaan yang Berada pada Indeks LQ45 di Bursa Efek Indonesia Periode Tahun 2009-2013 (Studi Empiris Pada Perusahaan Lq45 Di Bursa Efek Indonesia). E-Journal S1 Ak Universitas Pendidikan Ganesha, 2(1), 1-11.

Suandewi, I. G. A. A. S. (2016). Rasio-Rasio Keuangan dan Return Saham. EJurnal Akuntansi Universitas Udayana, 16(1), 756-780.

Tryfino. (2009). Cara Cerdas Berinvestasi Saham. Jakarta: Transmedia.

Wiagustini, N. L. P. (2014). Manajemen Keuangan. Denpasar: Udayana University Press.

Yang, R., Xia, K., \& Wen, H. (2016). Venture Capital , Financial Leverage and Enterprise Performance. Procedia - Procedia Computer Science, 91(Itqm), 114121. https://doi.org/10.1016/j.procs.2016.07.048 